\title{
Validity, Practicality, and Effectiveness: The Last Step in Development of Entrepreneurship Education Based Role-Playing for Kindergarten
}

\author{
Hasmawaty ${ }^{*}$, Husain Syam, Abdul Saman \\ Postgraduate of Universitas Negeri Makassar, South Sulawesi, Indonesia \\ Received October 5, 2020; Revised December 4, 2020; Accepted December 13, 2020
}

\section{Cite This Paper in the following Citation Styles}

(a): [1] Hasmawaty, Husain Syam, Abdul Saman , "Validity, Practicality, and Effectiveness: The Last Step in Development of Entrepreneurship Education Based Role-Playing for Kindergarten," Universal Journal of Educational Research, Vol. 8, No. 12B, pp. 8092-8101, 2020. DOI: 10.13189/ujer.2020.082611.

(b): Hasmawaty, Husain Syam, Abdul Saman (2020). Validity, Practicality, and Effectiveness: The Last Step in Development of Entrepreneurship Education Based Role-Playing for Kindergarten. Universal Journal of Educational Research, 8(12B), 8092-8101. DOI: 10.13189/ujer.2020.082611.

Copyright $@ 2020$ by authors, all rights reserved. Authors agree that this article remains permanently open access under the terms of the Creative Commons Attribution License 4.0 International License

\begin{abstract}
Early childhood education plays an essential role in the development of children as a whole. For this reason, a primary and actual educational program is needed to prepare them for growing up. One of them is by introducing entrepreneurship education at the preschool level. This research is the final part of a research and development project to test whether the role-playing-based entrepreneurship education model developed is valid, practical, and effective. The research was conducted at the Islamic Kindergarten Cendikia Al Izhar Makassar, South Sulawesi, Indonesia. Furthermore, several groups of participants involved in this study were two experts, 2 Early Childhood Education (ECE) teachers, and 15 children. Data collection was carried out using: (1) device validation sheets, (2) teacher activity observation sheets, (3) children's activity sheets, (4) teacher response questionnaires, and (5) teacher response questionnaires. The collected data were then analyzed using quantitative methods by calculating the average value of this educational model's level of validity, practicality, and effectiveness. Based on the results of the study, it can be stated that the role-playing-based entrepreneurship education model for ECE children is proven valid, practical, and effective. This means that this educational model can be applied in the education system at the preschool level to acquire entrepreneurial knowledge and skills from an early age.
\end{abstract}

Keywords Entrepreneurship, Education Model,
Role-Playing, Effectiveness, Practicality, Validity

\section{Introduction}

Today, countries all over the world are faced with various crucial challenges in this 21st century. These challenges are related to external aspects such as globalization and economic orientation and radical changes in social dynamics that cannot be avoided [1]. Seeing this situation requires a political response from each country that is fast and precise and can impact the progress of a country that is competitive and able to achieve profitable economic growth [2]. The field of education, which is seen as an essential field that can support these challenges, tries to offer alternative options by proposing entrepreneurship education. The idea of entrepreneurship is a driver of economic growth and national prosperity. Entrepreneurship is considered an essential factor for a country's economic development [3].

Entrepreneurship education has become a global issue that has taken the public's attention and is considered an established academic discipline in the last few decades [4] [5] [6]. Not a few people argue about the existence of entrepreneurship, which is associated with education. Some people still use their traditional views to question entrepreneurship to perpetuate the greedy individual hero 
driven by his ambition for financial gain [7]. This view has even made many teachers reluctant to acknowledge entrepreneurship as part of the study of education [8].

Many studies review entrepreneurship education in various countries. However, almost all of these studies are still focused on adults, especially students [9] [5] [10] and children aged adolescents [11]. In other words, there are still minimal studies of entrepreneurship education aimed at children, especially in the preschool phase [12]. The same fact is expressed by Udu \& Amadi [13]. They claim that in most countries globally, entrepreneurship education programs are still concentrated in universities and have not been integrated into subjects for students in primary schools. The need for entrepreneurship education for young people aims to develop the skills needed to identify viable business opportunities someday [14]. Also, entrepreneurship education for children is useful to prepare them to face society's demands in the labor market, which has an unexpected direction in the next few decades [15] [16]. The teaching of entrepreneurship is also significant in building a more robust and more flexible society facing changing times [1]. Entrepreneurship also contributes to (a) economic growth, (b) rejuvenation of productive social networks, (c) relaunching of regional space, (d) dynamizing innovative processes, (e) creating new jobs [17].

Another important thing is that the application of entrepreneurship education is an essential effect on children's development. This type of education can increase aspects of (a) children's social awareness, (b) make them sensitive to problems around them, (c) provide opportunities to explore the right things, (d) help them create innovative solutions to their problems, and (e) support their ability to give opinions about the solutions they made [18]. Thus, it is essential to incorporate entrepreneurship teaching into the education system and promote better relations between educational institutions (schools) and the business world [19] [20].

The concept of entrepreneurship education raises new problems, one of which is what methods or strategies are appropriate to promote students. The application of entrepreneurship education is more efficacious [21]. Choosing the right learning method is very important for children to learn about entrepreneurship [22]. One of the learning methods suitable for early childhood is roleplaying. This method is considered appropriate because it is appropriate for the age and development level of the children.

There are several studies on entrepreneurship education in Indonesia aimed at young children. Yetti \& Azizah [23] stated that entrepreneurship education could increase the level of creativity of children. Entrepreneurship education at the preschool level covers four main themes: continuous reflection, active participation, meaningful learning situations, and a tolerant atmosphere [7]. The results of an empirical study at a kindergarten in
Yogyakarta, Indonesia, show that entrepreneurship learning can be carried out through various activities such as (a) holding a market day, (b) teaching children to sell, (c) having Friday sharing, and (d) learning to make a handicraft [24].

Of the several studies on entrepreneurship education, relatively few have tried to develop an entrepreneurship education model at the ECE level. The educational model is based on the role-playing method, which is one method that is very close to preschool children. This article examines the development phase of research and development to determine the level of validity, practicality, and effectiveness of this educational model.

\section{Literature Review}

\subsection{Validity, Practicality, and Effectiveness}

The quality of research and development products is measured. The developers are advised to carry out three types of validity, practicality, and effectiveness tests [25]. Validity is a measure of how well the data collected covers the actual investigation area [26]. That is, validity is a process of measuring what one should want to measure [27]. Validity can be divided into four types: face validity, criteria validity, content validity, and construct validity [28].

Content validity is a type of validity used in this study. Content validity is a subjective assessment of the operationalization of a particular construct. In other words, this validity is attest of the extent to which a measure appears to be related to specific instructions, which are usually associated with the appropriateness, readability, consistency of style and format, and clarity of the language used [29] [30]. To assess the validity is based on two criteria, namely: (a) the product developed is based on strong theoretical reasons and (b) the product developed has internal consistency [25].

The next type of test using to measure the quality of the development product is the practicality test. Practicality is part of the concept of usefulness of a trial and affects several aspects of a test. Also, practicality is defined as a measure of the extent. It can be practiced to generate and manage context and its use [31]. Thus, teachers who judge that the learning product is right and can be appropriately used by its users, namely teachers and students, are stated by a development product's practicality. Furthermore, Nieveen [25] explained that there are two criteria for practicality, namely: (a) the product developed can be applied according to expert and practitioner judgment and (b) product development can be applied in real terms in the field.

The final criterion in measuring the quality of the development product is the effectiveness test. Effectiveness is viewed from the consistency between the 
design/learning objectives with students' experience and learning outcomes [25]. The experience referred to in the statement is a form of appreciation through questionnaires or responses during the learning process. Furthermore, effective assessment is an assessment that considers the effect of the evaluation on student behavior and learning outcomes, in line with learning outcomes and curriculum, providing an assessment structure for subjects, and provides feedback afterward [32].

In determining whether a development product is effective or not, several aspects must be fulfilled. Some of these aspects include: (a) having clear objectives and readiness for the assessment, (b) involving stakeholders during the assessment process, (c) having to know about what they are going to judge, and (d) how they will judge them [33]. Also, Mustami et all. [34] stated that if $80 \%$ of students reached the minimum criterion score of 76.5, the learning model was effective.

\subsection{Entrepreneurship Education}

Entrepreneurship education starts with an entrepreneurial mindset. This mindset is defined as the ability to feel, act, and mobilize in uncertain conditions [35]. This mindset can be viewed from two perspectives, namely commercial activity and problem-solving promotion. The aspect of commercial activity involves groups and individuals who create marketable products and services [36]. On the other hand, the second aspect of the entrepreneurial mindset is highlighting the promotion of creative and innovative problem solving as a universally applicable skill [37].

Entrepreneurship education is based on a cognitive approach to entrepreneurship and entrepreneurial methods. This educational model supports an understanding of what entrepreneurial knowledge structures are, how they act and decide, develop an entrepreneurial spirit, skills, and abilities of every individual who wants to learn how to become an entrepreneur [37] [38]. Linan [39] states that entrepreneurship education is an overall educational and training activity in an educational and non-educational system that seeks to develop children's entrepreneurial intentions or factors that influence these intentions, such as knowledge, desire, and entrepreneurial activities.

There are several important goals for entrepreneurship education in the curriculum in educational institutions. One of the aims is to integrate entrepreneurial traits with entrepreneurial processes and entrepreneurial behavior [40]. That is, entrepreneurship education requires the transfer of business knowledge and management and develops new ways of thinking, attitudes, competencies, and behaviors [41] [42].

\subsection{Role-playing}

Role-playing is a form of learning model that is oriented towards new social interactions [43]. That is, role-playing emphasizes the formation of relationships between students with one another. This model departs from the paradigm that individuals can't escape from a cycle of interactions with other individuals. In a broader context, this relationship leads to the relationship between individuals and society. Therefore, the learning process must be a vehicle for preparing students to interact extensively with the community, develop democratic attitudes and behaviors, and foster the productivity of students' learning activities [44].

Role-playing is a learning strategy where students can perform specific roles with various activities, such as saying, doing, and sharing. Another definition states that role-playing is an approach to facilitating learning. It effectively achieves learning outcomes in three main learning domains, namely affective, cognitive, and behavioral [45]. In other words, this strategy allows participation in simulations of social situations intended to direct children to the child's life [46].

Theoretically, role-playing requires some or all students to play the role of a character or object. In other words, this method requires students to take specific roles and act and improvise certain roles with realistic criteria that bring them as close to reality as possible [47]. This condition requires students not to be silent. They will be active and dynamic. Role-playing is a planned learning activity designed to achieve specific educational goals [48].

Role-playing has the potential to engage children in a longer learning process that indirectly promotes critical thinking dispositions such as openness, fair thinking, persistence, and empathy [49]. This means that the role-playing model is more concerned with aspects of the process than aspects of content alone. This method also helps children develop critical thinking activities and apply their knowledge to real-life scenarios [50].

\section{Method}

\subsection{Research Design, Site, \& Participants}

This research is research and development focusing on the testing phase of the validity, practicality, and effectiveness of the products developed. The research and development design adopted in this study was Theory Borg \& Gall [51] which was modified into four main steps: the preliminary study stage, product design, development, and testing. These R\&D steps are clearly illustrated in Figure 1. 


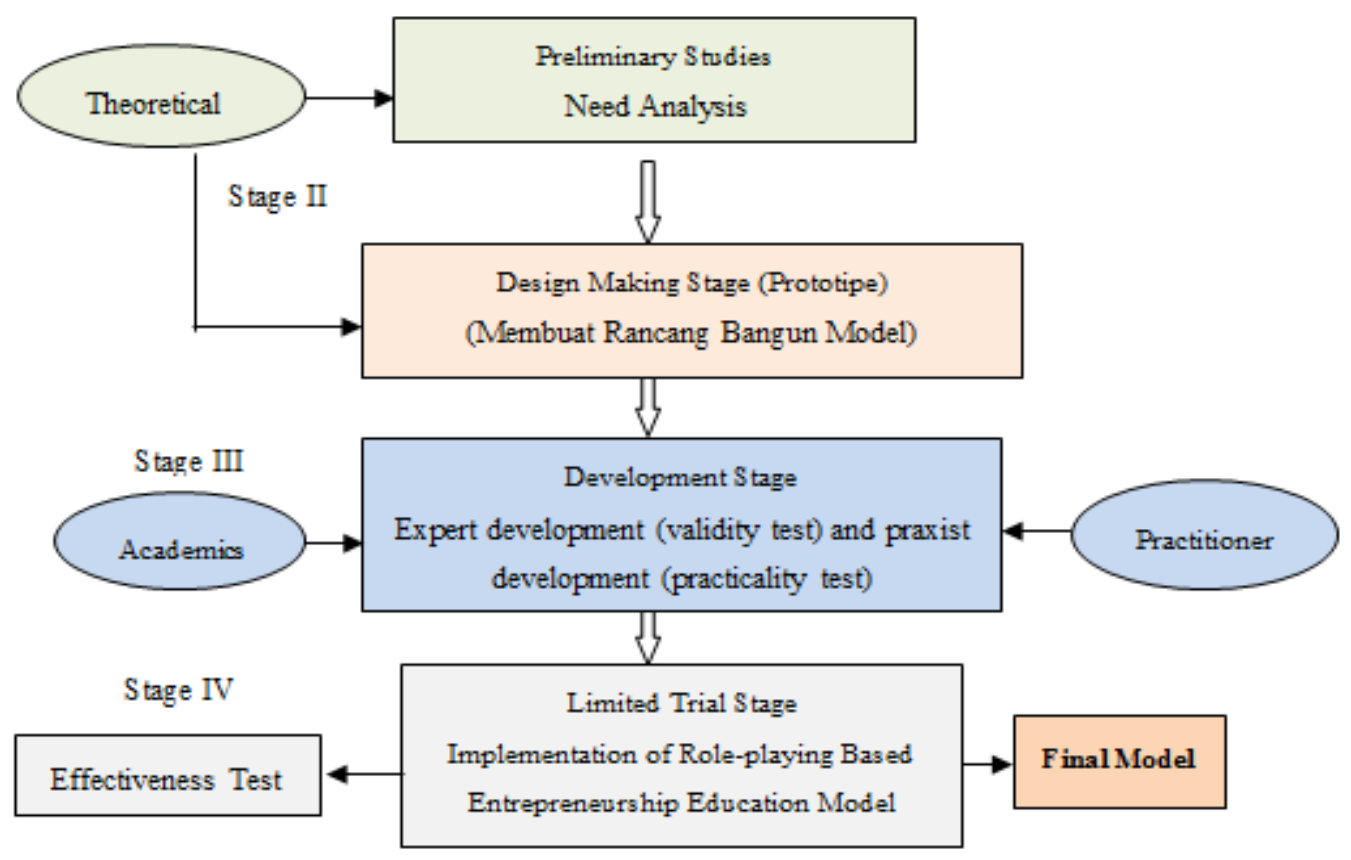

Chart 1. Research \& development flow

This article is devoted to reviewing the development phase (validity and practicality testing) and the limited trial phase (effectiveness test) of developing a role-playing-based entrepreneurial education model. The research was conducted at the Islamic Kindergarten Cendikia Al Izhar Makassar, South Sulawesi, Indonesia. There are three groups of participants involved in this study, namely: (a) 2 experts/validators, (b) 2 kindergarten teachers, and (3) 15 students.

\subsection{Data Collection}

In research and development, the level of validity, practicality, and effectiveness of product development use several educational instruments [52]. To test the level of validity, researchers used a validation sheet for learning tools. Researchers also used: (a) teacher activity observation sheets, (b) children's activity observation sheets, (c) teacher response questionnaires to measure the practicality of development products. Finally, to measure the product's effectiveness, the researcher used the children's ability observation sheet to see an increase in their ability with the achievement of entrepreneurial values

\subsection{Data Analysis}

To determine the level of validity, practicality, and effectiveness of product development using quantitative methods, the data collected through these various instruments were analyzed to determine the average score for each category. The formula used to calculate the average value of validity, practicality, and effectiveness; the researchers used the following procedure.
1) Calculating the level of validity

Average total score $(\bar{X})=\frac{\sum \bar{A}_{i}}{n}$

Information:

$(\bar{X})=$ total mean

$\bar{A}_{i}=$ average of the $i$ aspect

$n=$ many aspects

After the total average value is obtained, the score is adjusted to the value range table, as stated by Gregory quoted by Ahmar \& Rahman [53] in table 1 .

Table 1. Categories of practical learning models

\begin{tabular}{|c|c|c|}
\hline No. & Score Range & Category \\
\hline 1. & $3,5 \leq \mathrm{X} \leq 4,0$ & Very valid \\
\hline 2. & $2,6 \leq \mathrm{X}<3,5$ & Valid \\
\hline 3. & $1,6 \leq \mathrm{X}<2,5$ & Quite valid \\
\hline 4. & $1<1,5$ & Invalid \\
\hline
\end{tabular}

2) The level of practicality

We are looking for the total average of each observation aspect to measure the learning implementation level using the formula proposed by Nurdin [54] in table 2.

$$
\overline{A_{i}}=\frac{\sum_{m=1}^{t} A_{m l}}{t}
$$

Information:

$\overline{A_{i}}=$ average of the $i$ aspect

$\mathrm{A}_{\mathrm{mi}}=$ average of the $i$ aspect meeting to $\mathrm{m}$

$\mathrm{t}=$ the number of meetings 
Table 2. Categories of learning model engagement attainment

\begin{tabular}{|c|c|c|}
\hline No & Score Range & Category \\
\hline 1. & $2.5<\mathrm{A} \leq 3.0$ & Performed very well \\
\hline 2. & $1.0<\mathrm{A} \leq 2.5$ & Well done \\
\hline 3. & $0<\mathrm{A} \leq 1.0$ & Not done \\
\hline
\end{tabular}

3) The level of effectiveness

To measure the learning model's effectiveness, researchers conducted observations of students' activities using the Child Activity Observation Sheet (CAOS) instrument in learning activities based on a role-playing-based entrepreneurship education model. They described according to Nurdin's [54] in table 3.

Table 3. Model effectiveness score interval

\begin{tabular}{|c|c|}
\hline Interval (\%) & Category \\
\hline $\mathrm{CA}<25$ & Very low \\
\hline $25 \leq \mathrm{CA}<50$ & Low \\
\hline $50 \leq \mathrm{CA}<75$ & High \\
\hline $75 \leq \mathrm{CA} \leq 100$ & Very high \\
\hline
\end{tabular}

Information: $\mathrm{CA}=$ Child Activity

\section{Results}

\subsection{Validity Test Results}

The validity test of the development product in this study was carried out by asking for experts' responses. Two experts were involved in this study to assess the learning model developed. The results of the data analysis from the experts are presented in table 4.

Based on Table 4, information is obtained that the development products that have been validated meet the very valid criteria. The model book validation results got an average score of 3.6 from the results of the two experts' assessment, while the model manual obtained an average score of 3.5. Other development products that are validated are semester programs and Weekly Learning Program Plans (WLPP). The two products got an average score of 3.7 and 3.67, which can be categorized as very valid. Finally, two other validated development products are the Daily Learning Program Plan (DLPP) and the assessment sheets of students who get a score of 3.54 and 3.63 , which are categorized as very valid. Overall, all development role-playing-based entrepreneurship education model products' validity value is within the interval limit of $3.50 \leq \mathrm{V}<4.0$, which means that all of them are in a very valid category.

Table 4. Recapitulation of product validation results

\begin{tabular}{cccc}
\hline \multirow{2}{*}{ No. } & Products developed & \multicolumn{2}{c}{ Validity } \\
& Average & Category \\
\hline 1. & Model book & 3.6 & Very Valid \\
2. & Teaching manual book & 3.5 & Very Valid \\
3. & $\quad$ Semester program & 3.7 & Very Valid \\
4. & $\begin{array}{c}\text { Weekly Learning Program } \\
\text { Plan (WLPP) }\end{array}$ & 3.67 & Very Valid \\
5. & $\begin{array}{c}\text { Daily Learning Program } \\
\text { Plan (DLPP) }\end{array}$ & 3.54 & Valid \\
6. & $\begin{array}{c}\text { Student Assessment Sheet } \\
\text { (SAS) }\end{array}$ & 3.63 & Very Valid \\
\hline
\end{tabular}

\subsection{Practicality Test Results}

The practicality test was carried out by giving a response questionnaire to two teachers. Respondents were asked to rate development products in this research, such as Daily Learning Program Plans (DLPP), textbooks, assessment rubrics, and learning activities. The teacher is also asked to assess the presentation aspects and the appropriateness of the product's language. The results of data analysis from the questionnaire are presented in table 5. 
Table 5. Results of practicality scores by the teacher

\begin{tabular}{|c|c|c|c|}
\hline No & Assessment Aspects & Average & Category \\
\hline \multicolumn{4}{|c|}{ Learning Media } \\
\hline 1 & Daily Learning Program Plan (DLPP) & 3.8 & Very Practical \\
\hline 2 & Textbooks & 3.4 & Practical \\
\hline 3 & Assessment rubric & 4.0 & Very Practical \\
\hline 4 & Learning Activities & 3.8 & Very Practical \\
\hline 5 & Generating motivation and interest in learning and children's curiosity & 3.7 & Very Practical \\
\hline \multicolumn{4}{|c|}{ Presentation Eligibility } \\
\hline 6 & By the child's level of development & 3.7 & Very Practical \\
\hline 7 & Encourage children to be actively involved & 3.8 & Very Practical \\
\hline 8 & Interesting and fun & 3.2 & Practical \\
\hline 9 & By the teacher's level of ability & 3.5 & Very Practical \\
\hline 10 & Use the right and correct Indonesian. & 3.6 & Very Practical \\
\hline \multicolumn{4}{|c|}{ Language Eligibility } \\
\hline 11 & Clarity of message & 4.0 & Very Practical \\
\hline 12 & The standardization of terms and symbols used & 3.3 & Practical \\
\hline 13 & $\begin{array}{l}\text { In accordance with the Standards for Child Development Achievement } \\
\text { Level (CDAL) }\end{array}$ & 3.7 & Very Practical \\
\hline 14 & In accordance with the indicators of child development & 3.5 & Very Practical \\
\hline & Total Average & 3.64 & Very Practical \\
\hline
\end{tabular}

The results of the target user (teacher) test to measure the practicality of model books and role-playing-based entrepreneurship education teaching manuals are presented based on the practicality components of the product with average values, as follows:

1) Daily Learning Program Plans (DLPP) get an average score of 3.80 in the very practical category.

2) Textbooks get an average score of 3.40 in the very practical category.

3) The assessment rubric obtained an average score of 4.0 in the very practical category.

4) Learning activities get an average score of 3.80 in the very practical category.

5) We generate motivation and interest in learning as well as the curiosity of children with an average score of 3.70 in the very practical category.

6) According to the child's level of development, the average score is 3.70 in the very practical category.

7) Encourage children to be actively involved, get an average score of 3.80 in the very practical category.

8) Exciting and fun, get an average score of 3.20 in the practical category.

9) According to the level of the teacher's ability to obtain an average score of 3.50 in the very practical category.

10) Using good and correct Indonesian, get an average score of 3.60 in the very practical category.

11) he clarity of the message receives an average score of 4.0 in the very practical category.
12) The standardization of terms and symbols used obtained an average score of 3.30 in the practical category.

13) Following the Child Development Achievement Level Standards (CDALS), getting an average score of 3.70 in the very practical category.

14) According to the indicators of child development, the average score is 3.50 in the very practical category.

\subsection{Effectiveness Test Results}

Using the product (model books and teaching manuals) begins by observing firsthand using the product by the teacher and using communication media. During the process of using the product, the researcher still asks for suggestions and input from the teacher on matters that require attention and the effects of using model books and teaching manuals. Assessment of age children is more concerned with observations made during the ongoing process.

For this reason, the assessment is carried out not using a "paper and pencil test" but rather direct observation of children's activities. The assessment carried out in early childhood is carried out by observing or observing the learning activities they carry out by assessing entrepreneurial attitudes. Assessment of children's entrepreneurial attitudes is carried out by using an observation sheet by providing a checklist on aspects that, according to the observer's observations, are by the child's results or activities as measured through a 
performance test. The results of the observations can be presented in table 6 .

Table 6. Statistical results for children's assessments

\begin{tabular}{|c|c|}
\hline Variable & Statistical Score \\
\hline Research subject & 15 \\
\hline Ideal score & 4 \\
\hline Average score & 2.5 \\
\hline Highest score & 4 \\
\hline Lowest score & 1 \\
\hline Score Range & $\mathbf{1 . 5}$ \\
\hline
\end{tabular}

Table 6 shows that the average score of the students' ability of Group B TK Islam Cendekia Al Izhar Makassar is 2.67 with the ideal score that might be achieved is 4 , the highest score is four, and the lowest score is 1 with a score range of 1.5 .

If the students' ability scores are grouped into four categories, then the frequency distribution is obtained in table 7.

Table 7. Effectiveness test results

\begin{tabular}{|c|c|c|c|}
\hline Score Range & Frequency & Category & Percentage \\
\hline $3.5<\mathrm{X} \leq 4.0$ & 11 & Very high & $73.33 \%$ \\
\hline $2.5<\mathrm{X} \leq 3.5$ & 4 & high & $26.67 \%$ \\
\hline$<\mathrm{X} \leq 2.5$ & 0 & Low & $0 \%$ \\
\hline $1.0<\mathrm{X} \leq 1.5$ & 0 & Very low & $0 \%$ \\
\hline Amount & $\mathbf{1 5}$ & & $\mathbf{1 0 0} \%$ \\
\hline
\end{tabular}

Table 7 shows that of the 15 students, 11 students, or $73.33 \%$, were in the very high category, four students, or $26.67 \%$, were in the high category, and no students, or $0 \%$, were in a low category. Thus, it can be concluded that children's entrepreneurial attitude is "very well developed" with an average score of achievement of entrepreneurial values of students of Al Izhar Makassar Islamic Kindergarten students in the "very high" category.

\section{Discussion}

Research and development need to be carried out at all levels of education, including at the ECE level. So far, many researchers, teachers, and lecturers have used this type of research with a focus on entrepreneurship education at the elementary, middle school, and tertiary education levels [55]. This fact has neglected the important role of preschool and the compulsory school itself [56]. For this reason, it is necessary to introduce entrepreneurship education for childhood and adolescence [57] and preschool children [58].

The development of the learning model requires a validation test to determine the extent of the product's validity that has been developed. This test involves several experts to correct and provide input on products that have been developed. The validation test results in this study indicate that all products that have been developed are proven to be very valid based on the calculation of the average score of the two validators. The assessment aspects in a validation test usually vary, such as adequacy, coherence, suitability, and usefulness [59].

The user's target test analysis results were carried out to measure model books' practicality and role-playing-based teaching manuals on entrepreneurship education models. The analysis results show that the product development model of entrepreneurship education based on role-playing has an average score of 3.64 in the very practical category, so it can be concluded that the product development has met the criteria for product practicality. A development product is declared practical if it meets the following aspects: (a) the teacher's assessment states that the model can be applied with minor revisions, and (b) the model can be implemented because it is by the applicable curriculum, time allocation, and school conditions [60].

The results of testing entrepreneurship learning tools with the role-playing method obtained data on learning outcomes (acquisition of entrepreneurial attitudes). The learning outcomes of entrepreneurship in the students of Islamic Kindergarten Al Izhar Makassar from 15 students were 11 students, $73.33 \%$ were in the very high category, and four students or $26.67 \%$ were in the high category. From this data, it shows that role-playing activities can stimulate the entrepreneurial attitude of children. Thus, effectiveness can also be seen from two aspects, namely: (a) achieving goals by the priorities set, (b) having conformity with needs, and (c) having a positive effect on increasing knowledge, attitudes, and behavior [61].

The achievement of validation test scores, practicality tests, and effectiveness tests can not be separated from the selection of role-playing learning methods. That is adapted to the development of this entrepreneurial education model. The role-playing method is considered according to the age level of children in kindergarten/early childhood because it has a combination of play and learning in it. Role-playing is also considered to have the capacity to change children's behavior [44] [62]. This method is also claimed to be able to build their opinions and thoughts, build language at its level [63] [64], lead to more extended absorption and retention of information [65], support group cooperation activities and creativity [48] [66], and act in situations based on children's understanding [67] [68].

In the Indonesian context, researchers have conducted many research and development in the field of entrepreneurship education. Farida et al. has developed an entrepreneurship education learning model specifically for university students [69]. This research only focuses on developing a project-based entrepreneurship education model to increase the entrepreneurial spirit of students. These studies indicate that the entrepreneurship education model is declared valid by experts and proven effective 
with a probability value of 0.046 . Unfortunately, this study only uses a test of validity and effectiveness without adding a practicality test.

Another study on this topic was conducted by Sari et al. [70] by developing a local potential-based entrepreneurship learning model in West Kalimantan Province, Indonesia. This learning model is specifically for vocational high school students. Like previous studies, the learning model also developed only tests the product development's validity and effectiveness. The validity test in this study reached an average value of 3.65 and was categorized as very valid. The effectiveness test results showed that the post-test scores were higher than the pretest scores in all aspects, namely the knowledge, skills, attitudes, and products produced by students with a score of 2.9 and above, which were categorized as medium and high.

Research and development are still relatively new in the field of education when compared to other areas. This can be seen from the lack of research on developing an entrepreneurial education model at all levels of education, especially preschool education (early childhood). This study is expected to open opportunities for researchers to explore more deeply the importance of this topic. In other words, this research is expected to become a research pilot in entrepreneurship, which is specifically for young children so that they have the skill and entrepreneurial attitudes as provisions in their future lives.

\section{Conclusions}

This research is a research and development to develop a role-playing-based entrepreneurship education model for Early Childhood Education (ECE) children. Based on the research results, this educational model is considered valid, practical, and effective. The level of validity is obtained through a validation test involving two experts to assess product development. This learning model's practicality level is obtained through a questionnaire aimed at teachers to evaluate the learning tools developed, aspects of language feasibility, and presentation aspects. The level of validity and practicality, development products are also tested for their effectiveness through the learning process. The effectiveness test results by observing children's activities obtained a percentage of $100 \%$, which states that this development product effectively stimulates children's entrepreneurial attitude aspects. Thus, it can be concluded that the developed product in the form of a role-playing-based entrepreneurship education model for ECE children is proven to be valid, practical, and effective and worthy of wider use.

\section{Acknowledgments}

The author would like to thank the Islamic
Kindergarten Cendikia Al-Izhar Makassar and Makassar State University for supporting the implementation of this research.

\section{REFERENCES}

[1] A. do Paço and M. J. Palinhas, "Teaching Entrepreneurship to Children: A Case Study," Journal of Vocational Education and Training, vol. 63, no. 4, pp. 593-608, 2011, doi: 10.1080/13636820.2011.609317.

[2] V. Johansen, "Entrepreneurship Education and Entrepreneurial Activity,” IntEnt 2007-17th Global Conference, Internationalizing Entrepreneurship Education \& Training, 2007.

[3] P. G. Audia, E. A. Locke, and K. G. Smith, "The Paradox of Success: An Archival and Laboratory Study of Strategic Persistence Following Radical Environmental Change,” Academy of Management Journal, vol. 43, no. 5, pp. 837853, 2000.

[4] T. Bae, S. Qian, C. Cmiao, and J. O. Fiet, "The Relationship between Entrepreneurship Education and Entrepreneurial Intentions: A Meta-analytic Review," Entrepreneurship Theory \& Practice, vol. 38, no. 2, pp. 217-254, 2014, doi: 10.1111/etap.12095.

[5] A. Fayolle, "Personal Views on the Future of Entrepreneurship Education,” Entrepreneurship Theory and Regional Development, vol. 25, no. 7-8, pp. 692-701, 2013.

[6] G. Nabi, F. Linan, A. Fayolle, N. Kruenguer, and A. Walmmsley, "The Impact of Entrepreneurship Education in Higher Education: A Systematic Review and Research Agenda," Academy of Management Learning \& Education, vol. 16, no. 2, pp. 277-299, 2017.

[7] K. Axelsson, S. Hägglund, and A. Sandberg, "Entrepreneurial Learning in Education Preschool as a Take-off for the Entrepreneurial Self," Journal of Education and Training, vol. 2, no. 2, pp. 40-58, 2015, doi: 10.5296/jet.v2i2.7350.

[8] M. Korhonen, K. Komulainen, and H. Raty, "Not Everyone is Cut Out to be The Entrepreneur Type: How Finnish School Teachers Construct The Meaning of Entrepreneurship Education and The Related Abilities of The Pupils," Scandinavian Journal of Educational Research, vol. 56, no. 1, pp. 1-19, 2012, doi:10.1080/00313831.2011. 567393.

[9] G. Nabi, F. Linan, A. Fayolle, N. Kruenguer, and A. Walmmsley, "The Impact of Entrepreneurship Education in Higher Education: A Systematic Review and Research Agenda," Academy of Management Learning \& Education, vol. 16, no. 2, pp. 277-299.

[10] E. Rideout and D. Gray, "Does Entrepreneurship Education Really Work? A Review \& Methodological Critique of The Empirical Literature on The Effects of University-based Entrepreneurship Education,” Journal of Small Business Management, vol. 51, no. 3, pp. 329-351, 2013.

[11] A. Fumero, A. De-Miquel, and F. J. Garcia-Rodriguez, "Promoting Entrepreneurial Potential in Adolescents: A Pilot Study Based on Intergenerational Contact," South 
African Journal of Business Management, vol. 46, no. 3, pp. 11-20, 2015.

[12] R. Fitriati, R. H. Lubis, S. Shakuntala, and D. Guntara, "Entrepreneurship Education The Models Applied in Certain Universities," International Journal of Administrative Science \& Organization, vol. 18, no. 3, pp. 239-251, 2011.

[13] C. S. Udu and U. P. N. Amadi, "Integrating Basic Entrepreneurship Studies into Primary Education Curriculum: Platform for Sustainable National Development," Academic Journal of Interdisciplinary Studies, vol. 2, no. 5, pp. 69-74, 2013.

[14] E. North, “A Decade of Entrepreneurship Education in South Africa,” South African Journal of Education, vol. 22, no. 1, pp. 24-27, 2002.

[15] S. Murgatroyd, “"Wicked Problems' and the Work of the School," European Journal of Education, vol. 45, pp. 259 279, 2010, doi: 10.1111/j.1465-3435-2010.01428.x.

[16] P. Sahlberg and D. Oldroyd, "Pedagogy for Economic Competitiveness and Sustainable Development," European Journal of Education, vol. 45, pp. 280-299, 2010, doi: 10.1111/j.1465-3435-2010.01429.x.

[17] J. Sánchez García, A. Ward, B. Hernández Sánchez, and L. Flores, "Entrepreneurship Education: State of the Art," Propósitos y Representaciones, vol. 5, no. 2, pp. 401-473, 2017, doi: http://dx.doi.org/ 10.20511/pyr2017.v5n2.190.

[18] M. Sarıkaya and E. Coşkun, “A New Approach in Preschool Education: Social Entrepreneurship Education,” Procedia -Social and Behavioral Sciences, vol. 195, pp. 888-894, 2015, doi: 10.1016/j.sbspro.2015.06.368.

[19] A. Lundstorm and L. Stevenson, Patterns and Trends in Entrepreneurship: SME Policy and Practice in Ten Economies. Orebro: Swedish foundation for Small Business Research, 2001.

[20] R. Klapper, "Goverment Goals and Entrepreneurship Education-An Investigation at A Grand Ecole in France," Education \& Training, vol. 46, no. 3, pp. 127-137, 2004.

[21] G. Zibeniene and R. Virbaliene, "Learning Methods of Entrepreneurship,” pp. 123-133, 2014.

[22] J. Hattie, Visble Learning for Teachers Maximing Impact on Learning. London: Routledge, 2011.

[23] E. Yetti and S. Aulia Azizah, "Improved Creativity in Early Childhood through Entrepreneurship Education," in 3rd International Conference on Early Childhood Education, 2017, vol. 58, pp. 399-403, doi: 10.2991/icece-16.2017.70.

[24] L. Rohmah, "Implementasi Entrepreneurship pada Anak Usia Dini di TK Khalifah Sukonardi Yogyakarta,” Al-Athfal: Jurnal Pendidikan Anak, vol. 3, no. 1, pp. 15-26, 2017.

[25] N. Nieveen, "Prototyping to Reach Product Quality,” in Design Approaches and Tool in Education and Training, J. Van Den Akker, R. M. Branch, K. Gustafson, and Nienke Nieveen, Eds. 1999.

[26] P. Ghauri and K. Gronhaug, Research Methods in Business Studies. Harlow: Prentice Hall, 2005.

[27] A. P. Field, Discovering Statistic Using SPSS. Newbury Park: Sage Publication, 2005.

[28] H. Taherdoost, "Validity and Reliability of Research
Instrument: How to Test the Validation of a Questionnare/ survey in a Research," International Journal of Academic Research in Management, vol. 5, no. 3, pp. 28-36, 2016.

[29] J. D. Brown, Using Surveys in Language Programs. Cambridge: Cambridge University Press, 2001.

[30] L. Bachman, Fundamental Consideration in Language Testing. Oxford: Oxford University Press, 1990.

[31] M. Zulkifli, "Model of Learning Information and Communication Technology Based: Study of Learning Islamic Education at Senior High School 4 Kendari,” IOSR Journal of Research \& Method in Education, vol. 3, no. 1, pp. 24-27, 2013.

[32] J. S. Kadir, M. Zaim, and R. Refnaldi, "Developing Instruments for Evaluating Validity, Practicality, and Effectiveness of the Authentic Assessment for Speaking Skill at Junior High School,” 2018.

[33] L. A. Braskamp and M. E. Enberg, Guidelines for Judging The Effectiveness of Assessing Student Learning. Chicago: Loyola University, 2014.

[34] M. K. Mustami, S. Syamsudduha, S. Safei, and M. I. Ismail, "Validity, Practicality, and Effectiveness Development of Biology Textbooks Integrated with Augmented Reality on High School Students,” International Journal of Technology Enhanced Learning, vol. 11, no. 2, pp. 187-200, 2019.

[35] R. McGrath and I. MacMillan, The Entrepreneurial Mindset. Boston, MA: Harvard Business School Press, 2000.

[36] H. M. Neck and D. G. Greene, "Entrepreneurship Education: Known Worlds and New Frontiers," Journal of Small Business Management, vol. 49, pp. 55-70, 2011, doi: 10.1109/emr.2012.6210514.

[37] S. D. Sarasvathy and S. Venkataraman, "Entrepreneurship as Method: Open Questions for An Entrepreneurial Future," Entrepreneurship Theory and Practice, vol. 35, pp. 113-135, 2011, doi: 10.1111/j/j.1540-6520.2010. 00425.x.

[38] J. C. Sanchez, T. Carballo, and A. Gutierrez, "The Entrepreneur from A Cognitive Approach,” Psicothema, vol. 23, no. 3, pp. 433-438, 2011.

[39] F. Linan, "Intention-based Models of Entrepreneurship Education,” Piccolla Impresa/Small Business, vol. 3, no. 1, pp. 429-441, 2004.

[40] M. de L. Cárcamo-Solís, M. del P. Arroyo-López, L. del C. Alvarez-Castañón, and E. García-López, "Developing Entrepreneurship in Primary Schools. The Mexican Experience of 'My first Enterprise: Entrepreneurship by Playing," Teaching and Teacher Education, vol. 64, pp. 291-304, 2017, doi: 10.1016/j.tate.2017.02.013.

[41] A. A. Gibb, "Entrepreneurship, Unique Solutions for Unique Environments. Can This be Achieved with The Exiting Paradigm?” 2006.

[42] C. Henry, F. Hill, and C. Leicht, "Entrepreneurship Education and Training: Can Entrepreneurial be Taught: Part I,” Education \& Training, vol. 47, no. 2/3, pp. 98-112, 2005.

[43] N. Ajleaa and N. Maarof, "The Effect of Role-play and Simulation Approach on Enhancing ESL Oral Communication Skills,” International Journal of Research in English Education, vol. 3, no. 3, pp. 63-71, 2018. 
[44] X. Qing, "Role-playing An Effective Approach to Developing Overall Communicative Competence," Cross-cultural Communication, vol. 7, no. 4, pp. 36-39, 2011.

[45] H. W. Maier, "Role Playing: Structures and Educational Objectives," Ejournal of the International Child and Youth Care Network, vol. 36, 2002.

[46] D. Rao and I. Stupans, "Exploring the Potential of Role Playing in Higher Education: Development of A Typology and Teacher Guidelines.," Innovations in Education and Teaching International, vol. 49, no. 4, pp. 427-436, 2012, doi: https://doi.org/10.1080/14703297.2012.728879.

[47] A. J. Moreno-Guerrero, C. Rodríguez-Jiménez, G. Gómez-García, and M. R. Navas-Parejo, "Educational Innovation in Higher Education: Use of Role Playing and Educational Video in Future Teachers' Training," Sustainability (Switzerland), vol. 12, no. 6, pp. 1-14, 2020, doi: 10.3390/su12062558.

[48] L. Castro and J. Villafuerte, “Strengthening English Language Teaching in Rural Schools through the Role-playing: Teachers' Motivations,” International Journal of Educational Methodology, vol. 5, no. 2, pp. 289303, 2019, doi: 10.12973/ijem.5.2.289.

[49] S. Rashid and S. Qaisar, "Role Play: A Productive Teaching Strategy to Promote Critical Thinking.," Bulletin of Education and Research, vol. 39, no. 2, pp. 197-213, 2017.

[50] Z. F. Ma, "Role Play as a Teaching Method to Improve Student Learning Experience of A Bachelor Degree Programme in A Transnational Context: An Action Research,” Compass: Journal of Learning and Teaching, vol. 13, no. 1, pp. 1-10, 2020.

[51] W. R. Borg and D. M. Gall, Educational Research. New York: Longman, 2003.

[52] Helaluddin, M. A. Ahmad, and Anshari, "Need Analysis of Academic Writing Teaching Model Based on Process-genre Approach: What Do They Really Need?,” Universal Journal of Educational Research, vol. 8, no. 10, pp. 4728-4735, 2020, doi: 10.13189/ujer.2020.081043.

[53] A. S. Ahmar and A. Rahman, "Development of Teaching Material Using An Android,” Global Journal of Engineering Education, vol. 19, no. 1, pp. 72-76, 2017.

[54] A. Nurdin, "Model Pembelajaran Matematika yang Menumbuhkan Kemampuan Metakognitif untuk Menguasai Perangkat Pembelajaran,” Unesa Surabaya, 2007.

[55] G. Gorman, D. Hanlon, and W. King, "Some Research Perspectives on Entrepreneurship Education, Enterprise Education and Education for Small Business Management: A Ten-year Literature Review," International Small Business Journal, vol. 15, no. 3, pp. 56-77, 1997, doi: $10.1177 / 0266242697153004$.

[56] K. Fuchs, A. Werner, and F. Wallau, "Entrepreneurship Education in Germany and Sweden: What Role Do Different School Systems Play?,” Journal of Small Business and Entreprise Development, vol. 15, no. 2, pp. 365-381, 2008, doi: 10.1108/14626000810871736.

[57] N. E. Peterman and J. Kennedy, "Enterprise Education: Influencing Students' Perception of Entrepreneurship,"
Entrepreneurship Theory and Practice, vol. 28, no. 2, pp. 129-144, 2003, doi: 10.1046/j.1540-6520.2003. 00035.x.

[58] L. Lindstrom, "What Do Children Learning at Swedish Preschools?” International Education Studies, vol. 6, no. 4, 2013, doi: 10.5539/ies.v6n4p236.

[59] D. V. Rogayan Jr. and L. F. Dollete, "Development and Validation of Physical Science Workbook for Senior High School," Science Education International, vol. 30, no. 4, pp. 84-290, 2019, doi: 10.33828/sei.v30.i4.5.

[60] A. Jaedun, V. L. Hariyanto, and N. E. Raharjo, "Pengembangan Model Pembelajaran Produktif Bermuatan Kewirausahaan,” Jurnal Kependidikan, vol. 1, no. 1, pp. 125-138, 2017.

[61] H. Hamdan, "Model Pengembangan Kreativitas dan Inovasi dalam Membentuk Entreperneur di Era Ekonomi Digital,” Journal Manajemen \& Kewirausahaan, vol. 7, no. 1, pp. 5968, 2019.

[62] K. R. Shangeetha, "Benefits and Shortcomings of Role-playing as a Speaking Activity in English Language Classrooms,” The English Teacher, vol. XXXIX, pp. 72-93, 2017.

[63] J. C. Yang and B. Quadir, "Effects of Prior Knowledge on Learning Performance and Anxiety in An English Learning Online Role-playing Game," Journal of Educational Technology \& Society, vol. 21, no. 3, pp. 174-185, 2018.

[64] R. Arham, A. H. Yassi, and B. Arafah, "The Use of Role Play to Improve Teaching Speaking,” International Journal of Scientific and Research Publication, vol. 6, no. 3, pp. 239-241, 2016.

[65] J. McCarthy and L. Anderson, “Active Learning Techniques Versus Traditional Teaching Styles: Two Experiments from History and Political Science," Innovative Higher Education, vol. 24, no. 4, pp. 279-294, 2000.

[66] T. Supartini, I. Th. J. Weismann, H. Wijaya, and Helaluddin, "Development of Learning Methods through Songs \& Movements to Improve Children's Cognitive and Psychomotor Aspects," European Journal of Educational Research, vol. 9, no. 4, pp. 1615-1633, 2020.

[67] D. M. Krebt, "The Effectiveness of Role Play Techniques in Teaching Speaking for EFL College Students,” Journal of Language Teaching and Research, vol. 8, no. 5, pp. 863-870, 2017, doi: 10.17507/jltr.0805.04.

[68] C. Febriyona, T. Supartini, and L. Pangemanan, "Metode Pembelajaran dengan Media Lagu untuk Meningkatkan Minat Belajar Firman Tuhan,” Jurnal Jaffray, vol. 17, no. 1, pp. 123-140, Apr. 2019, doi: 10.25278/jj71.v17i1. 326.

[69] E.K. Farida, E.T. Djatmika, B.N. Siswoyo, and M. Witjaksona, "Pengembangan Model Pembelajaran Kewirausahaan Berbasis Proyek untuk Menumbuhkan Semangat Wirausaha Mahasiswa Prodi Pendidikan Ekonomi IKIP PGRI Bojonegoro,” Jurnal Pendidikan Ekonomi \& Kewirausahaan, vol. 1, no. 1, pp. 8-18, 2017.

[70] R.U. Sari, R. Rusdarti, and R. Syamwil, "Pengembangan Model Pembelajaran Kewirausahaan Berbasis Potensi Lokal di Sekolah Kejuruan Wilayah Kalimantan Barat," Journal of Vocational and Career Education, vol. 2, no. 2, pp. 87-95, 2017. 